\title{
Abbreviations of Sources
}

\author{
1QapGen Genesis Apocryphon \\ $1 \mathrm{QH}^{\mathrm{a}} \quad$ Hodayot or Thanksgiving Hymns \\ 1QS Serek Hayahad or Community Rule \\ AB Anchor Bible \\ ABD Anchor Bible Dictionary. Edited by David Noel Freedman. 6 vols. New York: Double- \\ day, 1992 \\ ACSS African Christian Studies Series \\ AGJU Arbeiten zur Geschichte des antiken Judentums und des Urchristentums \\ AJEC Ancient Judaism and Early Christianity \\ AJSR Association for Jewish Studies Review \\ AMD Ancient Magic and Divination \\ AmEthno American Ethnologist \\ ANEM Ancient Near East Monographs \\ AnthCon Anthropology of Consciousness \\ AnthHor Anthropological Horizons \\ AnthT Anthropology Today \\ AOAT Alter Orient und Altes Testament \\ AQ Anthropological Quarterly \\ ARAnth Annual Review of Anthropology \\ AS Aramaic Studies \\ BASOR Bulletin of the American Schools of Oriental Research \\ BBR Bulletin for Biblical Research \\ BHS Biblia Hebraica Stuttgartensia. Edited by Karl Elliger and Wilhelm Rudolph. Stutt- \\ gart: Deutsche Bibelgesellschaft, 1983 \\ BI Biblical Illustrator \\ Biblnt Biblical Interpretation \\ Biblnters Biblical Intersections \\ BibOr Biblica et Orientalia \\ BJRL Bulletin of the John Rylands University Library of Manchester \\ BN Biblische Notizen \\ BrJPsych British Journal of Psychology \\ BT The Bible Translator \\ BTB Biblical Theology Bulletin \\ BThSt Biblisch-theologische Studien \\ BZAW Beihefte zur Zeitschrift für die alttestamentliche Wissenschaft \\ CBQ Catholic Biblical Quarterly \\ CBR Currents in Biblical Research \\ CCRM Cross Cultural Research and Methodology \\ CCS Clinical Case Studies \\ CD Damascus Document \\ CQS Companion to the Qumran Scrolls \\ CSCD Cambridge Studies in Christian Doctrine \\ CSCS Cambridge Studies in Cultural Systems
}


CSCO Corpus Scriptorum Christianorum Orientalium

CSHSMC Comparative Studies of Health Systems and Medical Care

CSRS Comparative Studies in Religion and Society

DCLY Deuterocanonical and Cognate Literature Yearbook

DDD Dictionary of Deities and Demons in the Bible. Edited by Karel van der Toorn, Bob Becking, and Pieter W. van der Horst. Leiden: Brill, 1995. 2nd rev. ed. Grand Rapids: Eerdmans, 1999

DJD Discoveries in the Judaean Desert

DSD Dead Sea Discoveries

EDSS Encyclopedia of the Dead Sea Scrolls. Edited by Lawrence H. Schiffman and James C. VanderKam. 2 vols. New York: Oxford University Press, 2000

EHLL Encyclopedia of Hebrew Language and Linguistics. Edited by Geoffrey Khan, Shmuel Bolozky, Steven E. Fassberg, Gary A. Rendsburg, Aaron D. Rubin, Ora R. Schwarzwald, and Tamar Zewi. 4 vols. Leiden: Brill, 2013.

EHPI Études d'Histoire et de Philosophie Ireligieuses

Ekstasis Ekstasis: Religious Experience from Antiquity to the Middle Ages

EJL Early Judaism and its Literature

ER Encyclopedia of Religion. Edited by Lindsay Jones. 2nd ed. 15 vols. Detroit: Macmillan Reference USA, 2005.

Ethnos Ethnos: Journal of Anthropology

Ethos Ethos: Journal of the Society for Psychological Anthropology

EvT Evangelische Theologie

ExpTim Expository Times

FAT Forschungen zum Alten Testament

FAT2 Forschungen zum Alten Testament 2. Reihe

FRLANT Forschungen zur Religion und Literatur des Alten und Neuen Testaments

GH Gender \& History

HALOT The Hebrew and Aramaic Lexicon of the Old Testament. Ludwig Koehler, Walter Baumgartner, and Johann J. Stamm. Translated and edited under the supervision of Mervyn E. J. Richardson. 4 vols. Leiden: Brill, 19941999

HAU HAU: Journal of Ethnographic Theory

HeyM Heythrop Monographs

Hist) The Historical Journal

HSM Harvard Semitic Monographs

HT History Today

HTR Harvard Theological Review

HTS Harvard Theological Studies

HUCA Hebrew Union College Annual

IBHS An Introduction to Biblical Hebrew Syntax. Bruce K. Waltke and Michael O'Connor. Winona Lake, IN: Eisenbrauns, 1990

IEJ Israel Exploration Journal

Int Interpretation

IOS Israel Oriental Studies

JAAR Journal of the American Academy of Religion

JAJSup Journal of Ancient Judaism Supplements

JANES The Journal of the Ancient Near Eastern Society

JAOS Journal of the American Oriental Society 


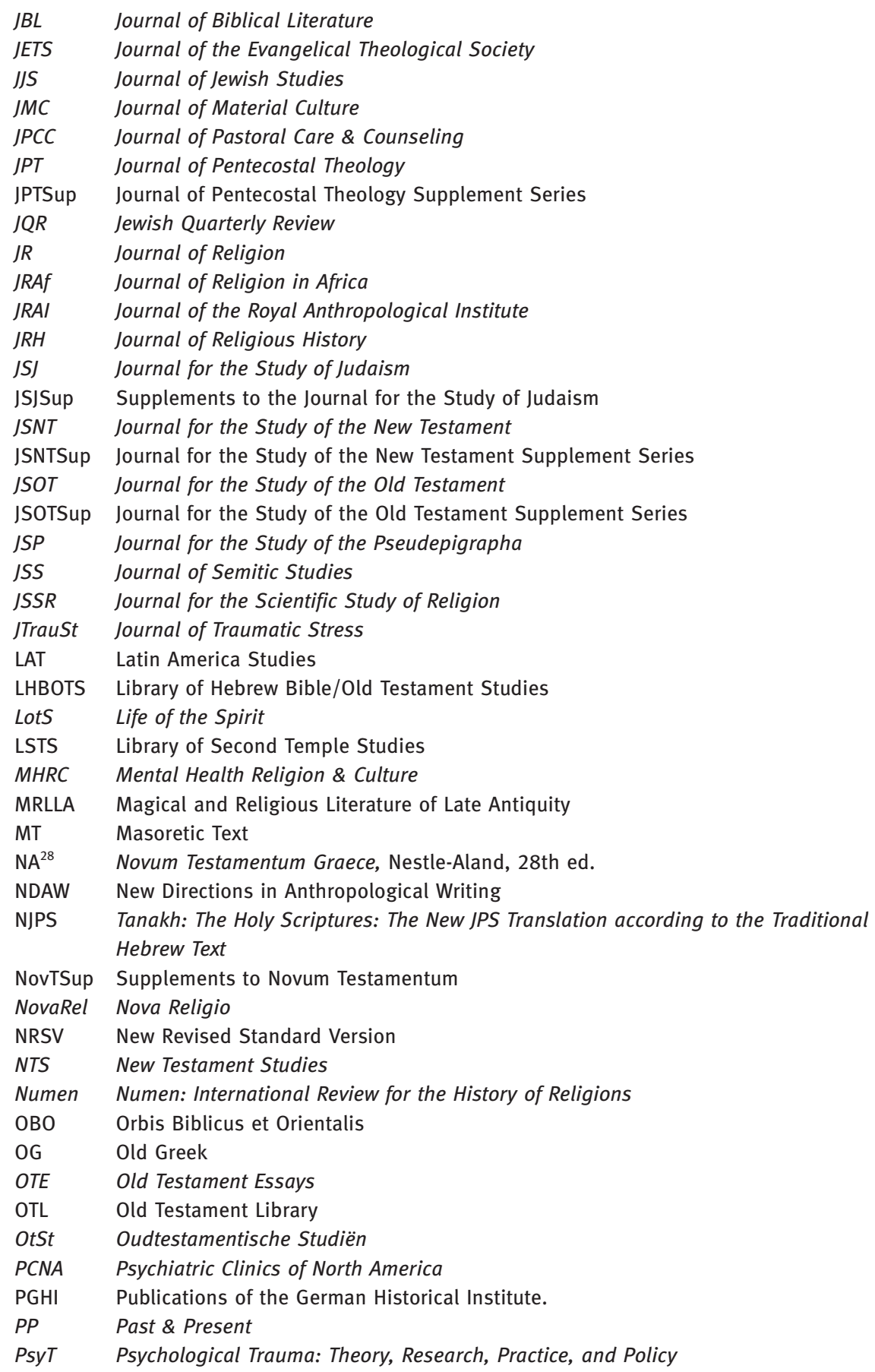




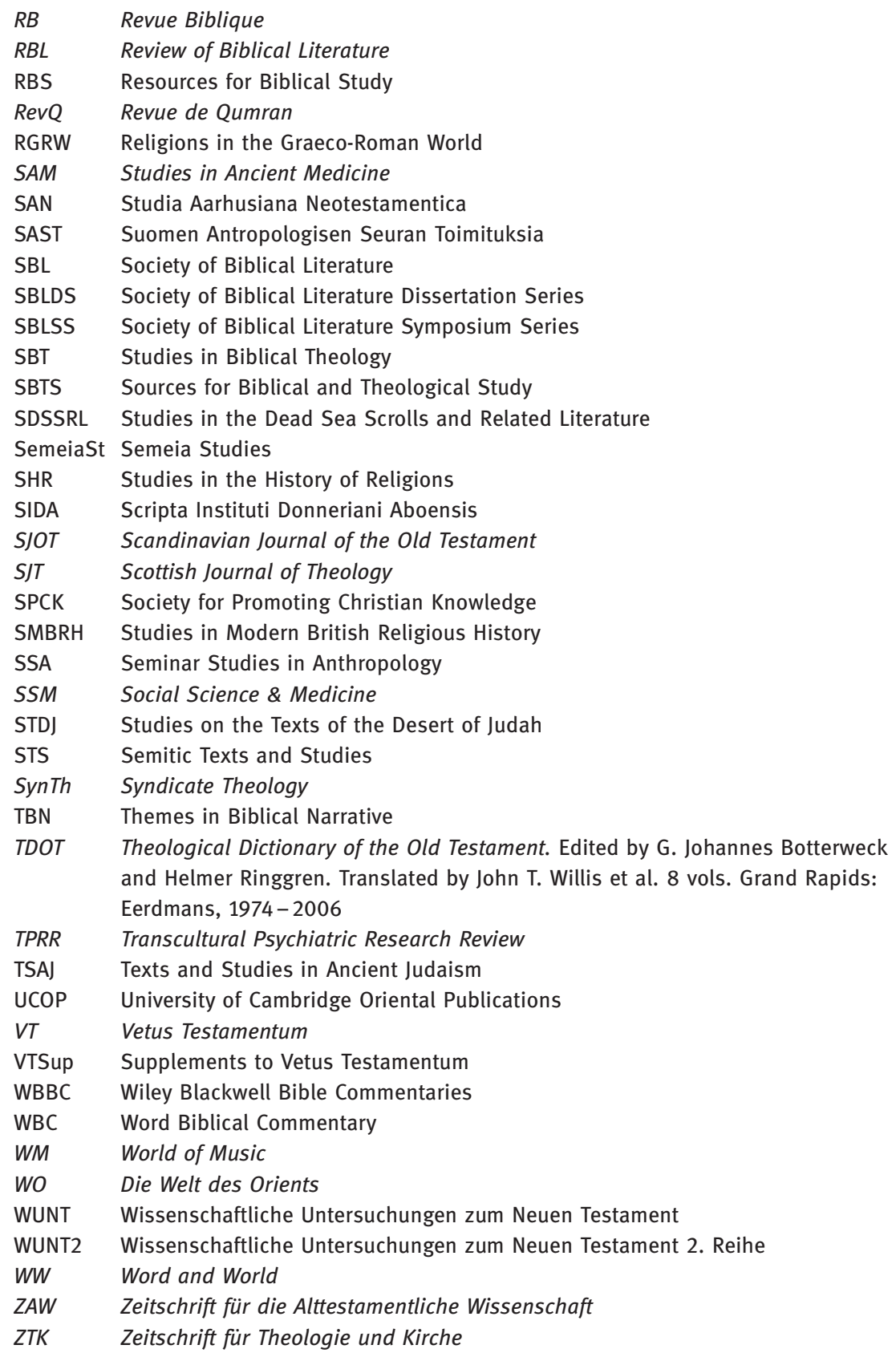

